\title{
THE MAIN DESIGN PRINCIPLES OF HYBRID SPACES IN TERMS OF THE URBAN PLANNING REGENERATION
}

\author{
E. Krasilnikova ${ }^{1}$, D. Klimov ${ }^{2}$ \\ ${ }^{1}$ FGBOU VPO Volgograd State Technical University \\ Lenin Avenue, 28, Volgograd, Russia, 400005 \\ ${ }^{2}$ FGBOU VPO Financial University under the Government of the Russian Federation \\ Leningradsky Prospekt, 49, Moscow, Russia, 125993
}

\begin{abstract}
Urban planning regeneration is a viable mechanism contributing to the urban development during complex reconstruction of the existing city space-planning structure. The dynamics of changing of urban planning theories and practices are characterized by an integral approach to city development through contradictory processes: intensification of globalization processes on the one hand; searching for identity on the other hand. Formation of hybrid spaces in urban fabric of modern cities is relevant and has significant socio-economic importance to the process of urban planning regeneration. In the context of permeability theory hybridity is determined as multi-layer, multi-functional feature of urban space, where there is no clear separation between public and private; buildings and facilities forming the structure are combined by multilevel public space where its virtual perception is also vey the important as well as its information capacity and its transformation ability. Hybrid spaces are multifunctional architectural and landscape entities, designed by applying the landscape urbanism approach and having the spatial connectivity with adjacent areas. The hybrid spaces are very importantt for the city economy, as they are development drivers to spatial, social and public changes. This research is aimed at defining modern design principles of hybrid spaces in terms of urban planning regeneration. The paper focuses on the principles of hybrid urban spaces design in the context of landscape urbanism such as the integration of dwelling areas and public spaces through the green infrastructure.
\end{abstract}

Key words: urban hybridization, integral urbanism, landscape urbanism, hybrid spaces

\section{INTRODUCTION}

The establishment of hybrid spaces in the modern city structure is directly connected with the social and economic processes of the city development and also with the current intensification of globalization processes (Figure 1). The territorial competitiveness is growing due to information permeability, infrastructure development and technological development. People tend to choose the most comfortable area for their residence, recreation and shopping.

The environmental quality of hybrid spaces is defined by its comfortability, multifunctionality and services interesting for: residents and business, tourists and investors, authorities and society $[1 ; 2]$.

In the city life and development, the hybrid spaces are rapidly growing city areas with self-organizing qualities, comprising the social and economic, functional and planning, recreation, landscape and composition, as well as environmental aspects. Space hybridization is based on the multifunctional connection with the internal city structure and the suburban areas. 


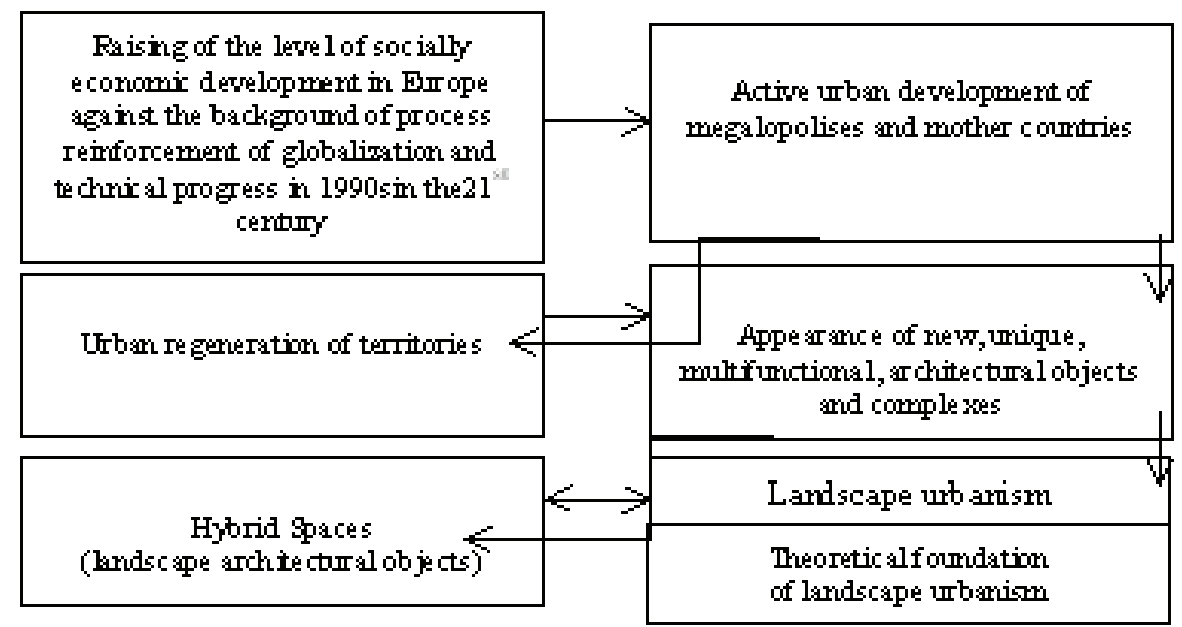

Figure 1. Background of hybrid spaces [8]

The environmental quality of hybrid spaces is defined by its comfortability, multifunctionality and services interesting for: residents and business, tourists and investors, authorities and society $[1 ; 2]$.

In the city life and development, the hybrid spaces are rapidly growing city areas with self-organizing qualities, comprising the social and economic, functional and planning, recreation, landscape and composition, as well as environmental aspects. Space hybridization is based on the multifunctional connection with the internal city structure and the suburban areas.

Today the tendency of hybrid spaces transformation into dominant nodal spaces in the city structure is observed. The functional saturation of hybrid spaces depends on the urban planning context and their location. Today the most popular are the hybrid spaces with the mixed structure of the spatial interaction between the residential, social and recreational functions.

Hybrid spaces allow to make city successful. There is four city development stages: 1) services offered within the regenerated area and the infrastructure begin to satisfy the citizens, companies and visitors; 2) new places of interest are developed to maintain the current business and provide public support to estimated business; 3) hybrid spaces highlight their peculiarities and advantages through an active and bright image or communication programme; 4) hybrid spaces are supported by citizens, public leaders and governmental agencies and thus attract new companies, investments and tourists.

It should be noted that the modern urban planning practice outruns the theoretical basis and concepts of hybrid spaces development and design.

\section{THE ROLE AND SIGNIFICANCE OF HYBRID SPACES FOR THE CITY DEVELOPMENT DURING THE POSTMODERNISM PERIOD. BACKGROUND OF HYBRID SPACES}

The period of postmodern urbanism (Ellin [3]) is characterized by predominance of the Anglo-American branch in theoretical concepts of the urban planning development. One of these branches is the landscape urbanism [4-7]. Landscape urbanism 
theory is connected with flexible, humane, creative, environmental and socially oriented regeneration approach. The approach aims at the active inclusion of nature into the city structure by maintaining its natural biodiversity to develop an identical and aesthetically attractive urban space. The landscape and urban approaches symbiosis defines a multidisciplinary trend in the landscape urbanism and the focus on hybrid spaces development (Figure 1). The application of the landscape urbanism principles in terms of the city space-planning structure transformation allows to form an urban socio-natural system. The complex approach allows to tackle difficult tasks concerning the urban spaces development at every urban planning level to create a comfortable urban environment.

By applying the main principle of the co-evolutionary approach [15] within the hybrid spaces development, especially the principle of nature and society cooperative development to define the main transformation directions of the existing urban planning structure, we can mitigate any negative effect of urban processes to create a sustainable and comfortable urban environment [8]. It is confirmed by the ideas of Frampton [18]. In his article "Architecture in the Age of Globalization", Frampton [18] concludes that the landscape cultural status has been changed in the age of postmodernism. Jencks [9] supposes that the postmodernist science of complexity, such as nonlinear dynamics, synergy, self-organization theory, chaos theory, dissipative structures theory, fractal geometry etc., have influenced and still are influencing the development of modern architectural thinking. It can be explained by the appearance of new types of multifunctional spaces - the hybrid urban spaces. Zanni [1] highlights that urban hybridization is determined by the multi-layered and multi-scaled urban tissue. In his view, it allows to create spaces in the city structure that connect its different parts according to cultural, historical and social context.

An analysis of functional and social interactions in the structure of hybrid buildings was carried out by Holl, Fernández Per, Mozas, Arpa [11], but they do not research the development of hybrid buildings in the context of landscape urbanism - from the point of the green infrastructure integration and the building structural arrangement.

Development of hybrid spaces in city structures began in the late 1980s. Parc de la Villette is a multifunctional architectural and landscape complex based on the urban planning regeneration of post-industrial abandoned areas and its surrounding working class areas in the 19th Paris district. The hybrid space development of the Parc de la Villette in the Parisian structure has influenced urban planning thinking and led to social and economic changes of its surroundings. It has also become a driver in urban transformations and changes carried out in this district of Paris (Figure 2). In the 1990s Paris, Barcelona and Canberra provided the first hybrid public recreational spaces, such as Promenade Plantée in Paris (by architect P. Mathieux and landscape architect J. Vergely, in 1993), Nus de la Trinitat Cloverleaf park, architects E. Batlle, J. Roig during 19921993), the National Museum of Australia, Canberra, architect R. Weller, during 19972001). Hybridization of the space-planning structure in these areas was the result of the design and creation of new public recreational space types, based on the integration of the landscape and the urban planning approaches towards the recreational objects planning in the city structure that differed from the common methods and techniques of the urban and landscape planning. 
Hybrid spaces are multifunctional architectural and landscape entities or landscape and urban planning entities, designed by applying the landscape urbanism approach and having the spatial connectivity with adjacent areas. The spatial connectivity of hybrid spaces with the urban tissue through the greenway public pedestrian space system allows to influence on the urban development of adjacent areas and the future city structure by becoming accessible urban space markers for all city residents.

Thus, we can conclude that hybrid spaces formation carried out by synergistic interactions between the formed architectural and planning structure, existing historical and urban context, the specifics of the socio-economic conditions, green infrastructure, etc.

In 1992, the Spanish architect Manuel de Solà-Morales revealed the trend of social and functional interaction of modern cities, involving the understanding of modern use of private and public spaces. Public spaces can be used for both private events and collective use, because they include the maximum number of functions. So, hybrid spaces appear in the urban tissue structure with typological and morphological variety [20].

The philosophy and practice of the hybrid space development in Western Europe and the USA is institutionally reflected in the economic development departments. For example, Ohio has established seven regional economic development agencies; each of them covers a group of districts. The agencies work with the districts and local authorities on establishment of hybrid spaces to improve the local business climate and meet certain needs of their territorial enterprises. Such scheme is applied in different countries such as Ireland, Bulgaria, and New Zealand, etc. It can be concluded that the hybrid space development is controlled by specific institutions to support and develop the city infrastructure.

\section{HYBRIDIZATION OF SPACE-PLANNING STRUCTURE AS AN URBAN PLANNING REGENERATION BRANCH}

The evolution of hybrid spaces in the 21 st century is based on the expansion of their functional saturation and the variation of their functional interaction. So, new types of hybrid spaces appeared in the early 21 st century with both the public recreational and the residential functions.

Generally such hybrid spaces appear in the structure of coastal areas; the best known examples of the hybrid space establishment with developed residential function are the Hamburg centre development project, based on the Hafen City district; regeneration of harbour areas by the River Liffey in Dublin (Dublin Docklands); the Embankment in the district Diagonal Mar i el Front Marítim del Poblenou in Barcelona; the surroundings of the Park of the Nations in Lissabon; the Western Harbour district in Malmö; the Havneholmen district in Copenhagen. These examples are characterized by the context approach towards the hybrid space formation, based on the maintaining and recovery of the natural environment that contributed to their image and identity and influenced the development of their surroundings and of the city as a whole [12].

Today the hybridization of the space-planning structure of post-industrial, damaged, ravaged or ineffectively used urban areas is a relevant branch of the urban regeneration (Figure 2). 


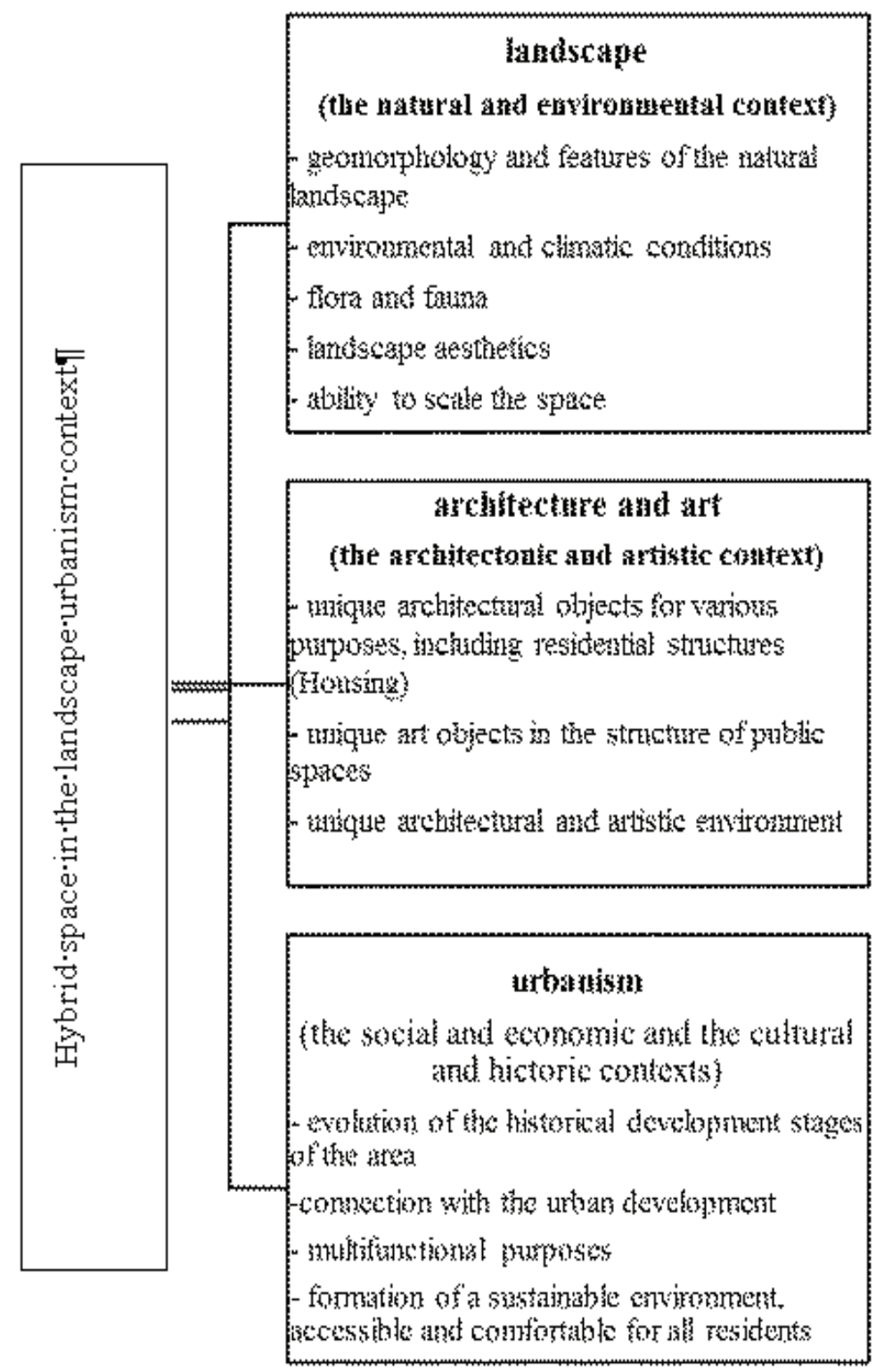

Figure 2. Hybrid spaces in the landscape urbanism context. The symbiosis of landscape, architecture, art and urbanism [8]

The functional heterogeneity of these areas allows to forecast their future development according to changes in the social and economic conditions and cultural preferences. The structural multifunctionality of hybrid spaces produces synergistic effect that contributes afterwards to the creation of new functional interactions within the hybrid space structure. For example, mixing of both residential and social and business functions in the space structure generates the need for the shopping and recreational functions, this shows how the functional saturation of hybrid space is formed. It is worth noting that the synergistic effect, resulting from the functional integration, can appear only after the hybrid spaces in the central or rapidly developing city quarters. 
Territories adjacent to hybrid spaces become actively developed because of influence of close hybrid spaces. Impulse to the development of adjacent territories, particularly of residential quarters (Barcelona is the typical example) is given by public pedestrian spaces system and green infrastructure based on the permeability principle. Example of such urban planning interaction is urban planning regeneration of residential quarters adjacent to the embankment in the Diagonal Mar i el Front Marítim del Poblenou district, Barcelona and the project of new hybrid quarter La Sagrera, Barcelona were formed on the basis of inter-modal transport hub.

Hybrid spaces give impetus to the infrastructure development. Thus, the more the territory infrastructure is developed, the more opportunities for attracting various resources there can be.

\section{PRIORITY DESIGN PRINCIPLES OF HYBRID SPACES IN TERMS OF THE URBAN PLANNING REGENERATION}

Modern hybrid spaces in big cities structure have expressed a social recreational purpose with a developed residential or social function. Functional saturation of hybrid spaces with residential function is vertical: space is cleared to the fullest degree; the space is organized based on the multi-functional principle, multi-layered inter-cultural public promenade, such as hybrid spaces structure of the Sofia Embankment in Moscow is organized this way $[16 ; 21]$. This project is an example of an active interaction between the residential complex of public spaces and green infrastructure elements. Therefore, we can conclude that the formation of embankment hybrid spaces is based on the principles of the landscape urbanism theory [4], that allow to move flexibly from the urban environment to natural. Thus, we see the introduction of green infrastructure elements in the building and construction of residential and multifunctional complex planning through all design levels. This allows to create memorable image not only for each structures that form hybrid space, but also of the whole hybrid space. This is why the modern understanding of hybrid spaces context should be reasonably considered as a symbiosis of urbanized space and natural environment.

The urban planning regeneration methods and techniques are widely variable depending on specific features of urban planning potential of the territory in terms of city development. For example, hybrid spaces formation of ex-post-industrial territories within the city structure is connected to their new functional saturation. Hybrid spaces formation principles also depend on urban planning context of the territory and specifics of the social-economic and investment conditions of the urban planning regeneration [16].

Hybrid spaces formation enables the creation of economic environment which is an economy growth point for the external environment. This capacity is determined by the emerging "concentration" effect in trade. The "concentration" effect is emerging with the "hybridization" of social, business, residential, retail functions in the regenerated city territory.

The hybrid space with vast variety of intermediate functions enables the creation of conditions for new sectors: the incubation process development facilitates information 
exchange and innovations distribution process, transfer of knowledge, and improves business communication process.

Hybrid spaces formation within the regenerated territory is one of the urban planning mechanisms driving social-economical, investment, cultural, business city development.

From our point of view, it is worth identifying the priority design principles of hybrid spaces in terms of urban planning regeneration.

It is of vital importance to describe these main principles. They are contextual innovation principle, urban planning variability principle, functional planning flexibility principle, cross programming principle, scaling principle and landscape innovation principle.

\section{CONTEXTUAL INNOVATION PRINCIPLE}

The contextual innovation principle is based on human-scale and natural environmental leading to hybrid space characterized with friendliness, communicability and contextuality. Such hybrid space should reflect regional and landscape peculiarities of the territory. Historical continuance (genius loci) — namely, conservation and reconsideration of heritage - keeps the past in memory, preserves the identity of the area during formation of the new space-planning territory structure. The concept of the Sofia Embankment in Moscow [21] is based on the contextual innovation principle (Figures 3).

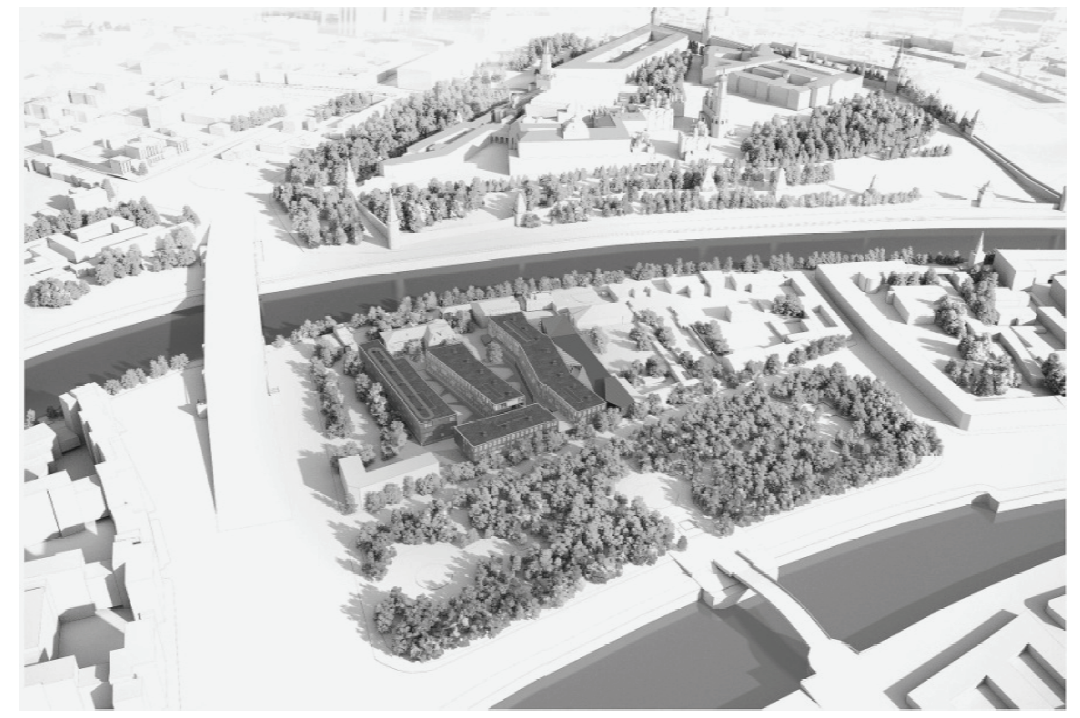

Figures 3. Example of hybrid space (Competition project -

Concept of multifunctional complex on the Sofia Embankment, Moscow, 2015. The territory of the Sofia Embankment in Moscow, 3D-model [21]

Adaptation of the project to its monumental environment is formed through upgrading of pedestrian arteries and historical routes that cross the adjacent city quarters, as well as through the adaptation of new housing developments to the neighbouring buildings and green spaces. 
Urban planning variability principle. The urban planning variability principle defines the urban planning capacities of the hybrid space under creation. This principle is based on the social-economic approach that enables the forecast of possible functional interaction options which in perspective should define the significance of the hybrid space for the development of its adjacent territories (quarters) and city planning structure. Prevailing dominant functions (residential, commercial, entertaining, recreational, etc.) within the hybrid space structure define its significance for the urban planning development. Based on the fact that social-economic conditions change affects the functional saturation and functional use of architectural planning and landscaping elements forming the hybrid space structure, it is necessary to forecast several options of urban planning scenario of hybrid spaces development depending on architectural planning and landscaping elements functional interactions.

The urban planning variability principle enables singling out of three types of communication with hybrid space that form the territory impression. The type of communication consists of landscape, infrastructure, spatial orientation, territory organization, leisure area. It means that first of all the architecture and city landscape are assessed but then the attention shifts to the city's conveniences: how the transport, communication, commercial services systems are developed. Further, the administration work is assessed: how influential the local authorities are and what kind of their efforts for maintaining and developing the territory are provided. The next factor is associated with the leisure services rendering: how comfortable the place for tourist is, what benefits and rewards for visitors are available, what events and entertainment are available for visiting. This criterion includes the estimate of the local authorities' efforts for investments attraction.

The hybrid space allows people to form an opinion on this territory, how competitive it is compared to other territories, what impressions people have from this area.

Thus, it seems that the hybrid space takes into consideration a wide range of factors affecting the image of the territory and enables an active interference in the territory development process creating favourable conditions for attracting investments.

Functional planning flexibility principle. The functional planning flexibility principle in hybrid spaces formation is based on the extension of their functional saturation "palette", which not only affects but also defines the capacities of the variability extension as to the architectural typology of buildings and constructions that form the hybrid space. This principle enables flexible introduction of hybrid spaces into the existing urban planning tissue for the creation of comfortable, environmentally friendly, socially oriented and identical urban environments. The urban planning regeneration of residential quarters of the North Fringe district, Dublin [8] and development of quarters Bo01, Bo02, Bo03, and Bo04 in the Western Harbour district, Malmö are the examples. This is a symbiosis of flexible housing planning structure with vast variability of typological solutions, provision of the quarters with the sites of various functional purposes, application of effective engineering infrastructure and modern environmentally sustainable technologies in the landscape organization of adjacent territories on the basis of preservation of their environmental potential. Flexibility of the planning solution increases capacities 
of the identical architectural space creation through the formation of individual architectural environment of residential and public architectural and landscaping complexes that form a hybrid space and are characterized by the functional diversity of the space use that affects the identity and aesthetics of style solutions.

Cross programming principle. The cross programming principle involves the functional provision of local elements of hybrid spaces infrastructure with certain functions based on the interaction and interrelation effect of intertwining functions. For instance, hybridization in formation of contact areas of hub dominant public spaces consists of functional interrelation of the linear public pedestrian promenade, local public spaces and residential complexes. Hybrid spaces formed within the embankments structure on the basis of urban planning regeneration and non-functioning railway tracks and trestles and deserted post-industrial territories can serve as an example $[8 ; 12 ; 16 ; 19]$.

Scaling principle. The scaling principle in hybrid spaces formation consists of urban planning typology extension in case of public and residential spaces depending on the specific urban planning context and size of territory. Territorial resource of certain city area defines the possibility of the hybrid space structure of public and residential space creation. This happens because of its urban context and functional purpose. As a result the areas become the image labels of the territory as well as accelerators for development of adjacent territories and city in general. (Example of Barcelona and Kaliningrad).

Landscaping environment adaptation principle. The landscaping environment adaptation principle is the return of the nature priority to the city spaces. This principle is based on the application of theoretical concept of landscape urbanism $[4 ; 6 ; 8]$. Through the scenario approach principle $[4 ; 8]$ local "green" and "blue-green" framework of public recreational spaces within hybrid spaces structure is formed [13]. Maximal inclusion of natural landscape components into the "green framework" structure is formed on the basis of biophilic approach application [10]. Structuring of the public recreational spaces is performed through the application of not only one main principle of theoretical landscape urbanism - use of horizontal surfaces $[4 ; 6 ; 8]$, but also in the "green infrastructure" formation [13] all the buildings and constructions forming hybrid spaces are involved regardless of their functional purpose. The formation of local green infrastructure of hybrid space is based on the scenario approach $[4 ; 8]$ should be integrated with transport framework of the territory and pedestrian links system, - this is how the connection with the adjacent territories is created (Porta Nuova, Varesine, Milan) [17].

General Conclusions and Reflection. The urban planning identity of hybrid spaces and social economic efficacy are the main and essential approaches to hybrid spaces formation through the different territorial levels. Described above, the priority principles of hybrid spaces formation provide the means for the creation of hybrid spaces as economically effective, investment attractive, unique and memorable city territories.

In order to create the scenarios of hybrid spaces development it is necessary to stray away from formal models in favour of more open strategic models where the landscape takes important part. Currently, the essential aspect of urban planning regeneration is the use of landscape as the tool creating new aesthetic effects, new social pro- 
grammes. Analysis of European and Russian experience presented in this research showed us that this approach is especially actively used in creation of hybrid spaces within developed residential function. Another important aspect is provision of hybrid spaces with various functions which enables more effective use of territorial resources, especially in central city parts with formed historical cultural environment. Thus, the analysed priority principles of hybrid spaces formation within the context of urban planning regeneration can be supplemented depending on the specific urban planning context and social economic development factors. Therefore, the integration of hybrid spaces into the city's tissue through the measures for activities efficacy increase is based on: prompt estimate of the territory potential: i.e. defining its main resources: historical, architectural, landscape, natural, social or industrial ones: it will help during the development of territory promotion strategy and the definition of the differentiating feature from other cities; consideration of hybrid space from the point of view of territorial location, i.e. defining the potential perspective development of the city's territory.

Mentioned examples of urban planning practices show that hybrid spaces are generally the markers for different functional parts of the city. Creating of unified architectural image of the hybrid space located in the central part of the city is connected with the fact that residential structures forming the hybrid space, usually "dissolve" - they are integrated into the architectural and planning context of hybrid space. This occurs on the due to the public spaces serve as the main communicator between them. Integration of residential complexes in the hybrid space structure occurs through active interaction with public, green spaces and transportation infrastructure.

(C) E. Krasilnikova, D. Klimov, 2016

\section{REFERENCES}

[1] Zanni, F., Urban hybridization, Politecnica: Milano, 2012.

[2] Ellin, N., Integral Urbanism, Routledge: New York, 2006. P. 18 -59.

[3] Ellin, N., Postmodern Urbanism, Princeton Architectural Press: New York, 1999. P. 60-153.

[4] Waldheim, C., Landscape as Urbanism A General Theory, Princeton University Press Princeton and Oxford: New Jersey, 2016.

[5] Waldheim, C., The Landscape Urbanism Reader, Waldheim Charles (eds), Princeton Architectural Press: New York, 2006.

[6] Corner, J. \& Hirsch, A. B., The landscape imagination. Collected Essays of James Corner 1990 - 2010, Princeton Architectural Press: New York, 2014.

[7] Mostafavi, M. \& Najle C., Landscape Urbanism: A Manual for the Mechanic Landscape, Architectural Association: London, 2003.

[8] Krasilnikova, E., Landscape Urbanism. Theory-Practice: Part.1. Scientific and practical foundations of landscape urbanism, scientific monograph: LTD «IAA «District news», Volgograd, 2015.

[9] Jencks, C., Architecture of the Jumping Universe: A Polemic. How Complexity Science is Changing Architecture and Culture. Academic Press: London, New York, 1995.

[10] Beatley, T., Biophilic Cities: Integrating Nature into Urban Design and Planning, Island Press: Washington, Kindle Edition, 2010. P. 1630-2415. 
[11] This is Hybrid. An analysis of mixed-use buildings. Fernández Per, A., Mozas, J., Arpa, J., $\mathrm{A}+\mathrm{t}$ Architecture Publishers, 2014.

[12] Krasilnikova, E. \& Antjufeev A., Creation of costal and recreation spaces on coastal territories, Strategic decision making in spatial development., peer-reviewed collection of contributions, ROAD and SPECTRA Centre of Exellence EU: STU, Bratislava, 2014. P. 59-87.

[13] Rouse, D. \& Bunster-Ossa, I., Green Infrastructure: A Landscape Approach, APA Planning Advisory Service: Chicago, 2013.

[14] A New Future for Planning, by Valeur H. (eds) // The Architectural Magazine B, 2005.

[15] Valeur, H., Co-Evolution: Danish/Chinese Collaboration on Sustainable Urban Development in China: Danish Architecture Centre, 2006. Online. http://www.aguilar-and-associates.com/ la-sagrera-new-intermodal-railway-station.

[16] Krasilnikova, E. \& Klimov, D., Role and value of landscape urbanism in the modern process of city development and reconstruction, Balkan Architectural Bienale // Conference proceedings „capital a“, BAB, Belgrade, Serbia, 2015. P. 21—40.

[7] Troshina, M., Milan waiting // Project International 38: Joint projects, 2014. P. 50—61.

[8] Frampton, K., Architecture in the Age of Globalization // Project International 18: Joint projects, 2007. P. 140-141.

[9] Krasilnikova, E., Landscape and urban planning transformation of space-planning structure // The Hybrid Link 03, Hybridization between Form and Energy, 2014. P. 1-26. Online. http://www. http://www.urbanhybridization.net.

[10] Avermaete, T., Hooimeijer, F., Schrijver, L., Urban Formation and Collective Spaces // OASE 71, NAi Publishers, 2006. Online. http://www.oasejournal.nl/en/Issues/71.

[11] Concept of multifunctional complex on the Sofia Embankment, Moscow, 2015. The finalist of competition - Miralles Tagliabue EMBT, Burgos \& Garrido arquitectos, TSNIIP, 2015. Online. http://archsovet.msk.ru/competitions/sofiyskaya-naberezhnaya/miralles-tagliabue-embt-sofnab.

\title{
ОСНОВНЫЕ ПРИНЦИПЫ ФОРМИРОВАНИЯ ГИБРИДНЫХ ПРОСТРАНСТВ В УСЛОВИЯХ ГРАДОСТРОИТЕЛЬНОЙ РЕГЕНЕРАЦИИ
}

\author{
Э.Э. Красильникова ${ }^{1}$, Д.В. Климов ${ }^{2}$ \\ ${ }^{1}$ Волгоградский государственный технический университет \\ проспект Ленина, 28, Волгоград, Россия, 400005 \\ ${ }^{2}$ Финансовый университет при Правительстве Российской Федерации \\ Ленинградский проспект, 49, Москва, Россия, 125993
}

Для жизнедеятельности и развития городов гибридные пространства представляют собой быстро развивающиеся территории города, обладающие свойствами самоорганизации в широком градостроительном аспекте - социально-экономическом, функционально-планировочном, рекреационном, ландшафтно-композиционном и экологическом. Динамика изменения градостроительной теории и практики характеризуется интегральным подходом к развитию городов в условиях протекания противоречивых процессов: усиления процессов глобализации, с одной стороны; поиска 
идентичности, с другой стороны. Формирование гибридных пространств в городской ткани современных городов является актуальным процессом и имеет важное социально-экономическое значение для градостроительной регенерации. В контексте теории проницаемости гибридность определяется как многослойная, многофункциональная особенность городского пространства, в котором нет четкого разделения между государственным и частным; здания и сооружения, образующие гибридную структуру, объединены многоуровневым общественным пространством, и его виртуальное восприятие играет также важную роль, определяя его информационную емкость и способность трансформации. Гибридные пространства представляют собой мультифункциональные архитектурно-ландшафтные или ландшафтно-градостроительные комплексы, которые формируются на основе приемов ландшафтного урбанизма и имеют пространственную связность с прилегающими территориями. Особое значение гибридные пространства имеют для экономики города, так как являются драйверами его развития, находящиеся на острие пространственных, социально-общественных преобразований. Целью данного исследования является поиск и определение современных научно-практических принципов формирования гибридных пространств в условиях градостроительной регенерации. В статье рассматриваются принципы формирования гибридных пространств в контексте ландшафтного урбанизма, а именно интеграция жилья и общественных пространств через зеленую инфраструктуру.

Ключевые слова: градостроительная гибридизация, интегральный урбанизм, ландшафтный урбанизм, гибридные пространства 